\title{
Patients with multiple sclerosis present low levels of empathy
}

\author{
Pacientes com esclerose múltipla apresentam baixos níveis de empatia \\ Marcos Barbosa de Almeida1, Luana Carramilo Going ${ }^{1,2}$, Yara Dadalti Fragoso ${ }^{2,3}$
}

\begin{abstract}
Multiple sclerosis (MS) is a chronic neuroimmunological disease that mainly affects young adults, leading to neurological disabilities over the course of their lives. Many psychiatric conditions have been reported in patients with MS, but there are remarkably few studies assessing empathy among these patients. Methods: This is a single center, cross-sectional study, of 34 patients with MS and 34 matched control subjects. A specific questionnaire (empathy quotient) was used. Results: Patients with MS showed significantly lower levels of empathy. This finding was not correlated with disease duration, degree of disability, drugs for treating MS or lesion load on resonance magnetic imaging. Conclusion: Decreased empathy is a frequent condition in patients with MS and should be addressed in order to diminish the psychosocial burden of this neurological disease.
\end{abstract}

Keywords: empathy; multiple sclerosis; psychology.

\section{RESUMO}

Esclerose múltipla (EM) é uma doença crônica neuroimune que afeta principalmente adultos jovens, levando a incapacidades neurológicas ao longo do curso de suas vidas. Diversas condições psiquiátricas foram relatadas em pacientes com EM, porém existem muito poucos trabalhos que avaliam empatia nestes pacientes. Métodos: Este foi um estudo transversal e unicêntrico com 34 pacientes com EM e 34 controles saudáveis pareados. Um questionário específico foi utilizado (Quociente de Empatia). Resultados: Os pacientes com EM mostraram níveis significativamente mais baixos de empatia. Este achado não estava correlacionado com a duração da doença, grau de incapacidade, droga utilizada no tratamento da EM ou carga lesional na ressonância magnética. Conclusão: Redução da empatia parece ser uma condição frequente em pacientes com EM e deve ser abordada para diminuir a carga psicossocial nos pacientes que apresentam esta doença neurológica.

Palavras-chave: empatia; esclerose múltipla; psicologia.

Multiple sclerosis (MS) is a chronic, demyelinating, autoimmune disease of the central nervous system. This condition typically affects young adults and accompanies them throughout life. Psychological and psychiatric comorbidities like depression, anxiety and social isolation are often reported in patients with this disease ${ }^{1}$. Demyelination can occur in several areas of the central nervous system and neurological disability may be the result of relapsing or progressive damage to axonal myelin².

Empathy is a complex state of mind that depends on the skill to project oneself into another person's situation. It involves sympathizing with and caring for the other person, while responding adequately to this projective experience $^{3}$. The motivational state of empathy is not only seen in humans, given that several animals can show support toward their mates. A typical example of empathy among rodents was seen in an experiment in which a caged rat was released but was kept restrained. ${ }^{4}$ Other rats, that were eating chocolate, went to release the restrained rat and they all shared the food ${ }^{4}$. Other mammals and even birds can show altruistic behavior towards those in distress $^{5}$. Although empathy is obviously affected by cultural, religious and parenting attitudes, every person has a degree of empathy towards human and animal suffering. However, certain neurological conditions may negatively affect social behavior, and the ability to understand and react to other people's feelings may be notably diminished. The connectivity of brain pathways, rather than a

'Universidade Católica de Santos, Departamento de Psicologia, Santos SP, Brasil;

${ }^{2}$ Universidade Metropolitana de Santos, Programa de Pós-Graduação, Santos SP, Brasil;

${ }^{3}$ Universidade Metropolitana de Santos, Departamento de Neurologia, Santos SP, Brasil.

Correspondence: Yara Dadalti Fragoso; Departamento de Neurologia da Faculdade de Medicina da UNIMES; Rua da Constituição, 374 ; 11015 -470 Santos SP, Brasil; E-mail:yara@bsnet.com.br

Conflict of interest: There is no conflict of interest to declare.

Received 06 July 2016; Received in final form 24 August 2016; Accepted 01 September 2016. 
simplistic view of specific area localization, seems to be responsible for empathic behavior ${ }^{6,7}$. In diseases like MS, empathy might be influenced by the extensive damage to several areas of the brain that is observable, as well as in individuals with no detectable abnormalities on resonance magnetic imaging ${ }^{5}$.

Empathy makes it possible to tune into someone else's feelings and thoughts. It allows us to foresee other people's intentions, understand their reasons, predict their behavior and experience emotions triggered by other people's emotions. It is more related to altruism than to compassion or sympathy, and it is a complex social skill acquired over the course of life li, $^{8 .}$.

There are remarkably few studies assessing empathy among patients with MS. A German case-control study showed a lower level of empathy among patients with MS in the early stages of the disease ${ }^{10}$. Another case-control study was carried out in the USA and confirmed these findings ${ }^{11}$. No other papers specifically report on empathy levels among patients with MS. The present study brings the first results from a case-control study on empathy and MS in a Brazilian population. Individuals living in Brazil differ culturally and genetically from those in the previous reports.

\section{METHODS}

This study was approved by the Ethics Committee of Universidade Metropolitana de Santos, SP, Brazil under the number CAAE 48995215.6.0000.5509. Patients attending the Reference Center for Multiple Sclerosis at the Department of Neurology of that institution were invited to take part in this investigation between August and September 2015. All patients included in this study fulfilled the criteria for relapsing-remitting $\mathrm{MS}^{12}$ and were stable on their medications for at least three months. All patients were undergoing treatment with disease-modifying drugs for MS, namely interferon beta $(n=11)$, glatiramer acetate $(n=18)$, natalizumab $(\mathrm{n}=3)$ and fingolimod $(\mathrm{n}=2)$.

The patients were sequentially invited while they were in the waiting room before their consultations and there were no refusals. Control subjects were obtained from the general population accompanying relatives at medical care units in the same area.

Demographic data were obtained from all patients and controls, in order to create the best possible matching between groups. There were no cases of missing data. Clinical data on the patients with MS were obtained from the consultation on the day of the assessment of empathy. Patients were not invited to participate if they had presented with a relapse in the previous 90 days. Patients and controls treated with corticosteroids within the last 90 days and those with a psychiatric diagnosis beyond mild anxiety or depressive traits ${ }^{13}$ were not included in this study.
The empathy quotient (EQ) was applied individually to all participants. This is a self-applied questionnaire comprising a list of 40 affirmative sentences with which participants note their degree of agreement. Another 20 unrelated sentences were scattered throughout the test, with the aim of distracting the individual from the subject under assessment. The questionnaire was developed in the United Kingdom ${ }^{14}$ and has been validated in several languages, including Portuguese $^{15}$. According to the scores obtained in the EQ, the individual is classified with one of the following degrees of empathy: lower than average, average, above average, very high, and maximal level of empathy. It is noteworthy that in relation to both health and diseases, women tend to score higher in empathy assessments than men ${ }^{16,17}$.

Clinical data on the patients were obtained, including disease duration and the degree of neurological disability measured by the expanded disability scale score ${ }^{18}$. Medication in use for treatment of MS was also taken into consideration in analyzing the EQ results. Data on acute and chronic lesions observed in magnetic resonance imaging examinations were analyzed to assess whether alterations in particular areas might be associated with levels of empathy. It is important to highlight that T1, T2 and T2-FLAIR in two dimensions were assessed. No other techniques were used, and there were no spectroscopy analyses and no functional imaging. Examinations were not always performed and reported by the same neuroradiologist. These facts may have limited the interpretation of data.

The sample size calculation indicated a target of 14 patients for the case-control study. GraphPad Prism was used for the statistical evaluation. Two-way and one-way ANOVA, chi-square analysis, linear regression analyses, Pearson's correlation and Student's t-test were used to assess the results. Significant values were those with $\mathrm{p}<0.05$.

\section{RESULTS}

The population included 34 patients with MS and 34 control subjects, matched for gender (10 males, 23 females) and age (median age $=35$ years). All the patients presented with the relapsing-remitting form of MS and were using immunomodulatory or immunosuppressive drugs to control the disease.

Summarized data on the levels of empathy among the patients and controls is presented in the Table. Briefly, while $40 \%$ of the patients with MS showed below-average empathy levels, no subject in the control group was classified in this category $(\mathrm{p}<0.0001)$

Average levels of empathy were shown by $60 \%$ of the patients and $85 \%$ of the control subjects $(p<0.01)$. However, the average scores obtained for the control subjects were significantly higher than those observed among the patients with MS ( $p<0.001)$. When the groups were divided according to 
Table. Summary of data on empathy in a case-control study.

\begin{tabular}{lcc}
\hline Variable & $\begin{array}{c}\text { Control group } \\
(n=34)\end{array}$ & $\begin{array}{c}\text { Patients with MS } \\
(n=34)\end{array}$ \\
\hline Median age & 35 years & 35 years \\
Gender & $10 \mathrm{M}, 23 \mathrm{~F}$ & $10 \mathrm{M}, 23 \mathrm{~F}$ \\
$\begin{array}{l}\text { Below average } \\
\text { empathy }\end{array}$ & 0 & $40 \%$ \\
$\begin{array}{l}\text { Average empathy } \\
\text { levels }\end{array}$ & $85 \%$ & $60 \%$ \\
$\begin{array}{l}\text { Above average } \\
\text { empathy }\end{array}$ & $15 \%$ & 0 \\
$\begin{array}{l}\text { Different empathy } \\
\text { levels M:F }\end{array}$ & Yes $(p<0.01)$ & No \\
\hline
\end{tabular}

MS: multiple sclerosis; M: male; F: female.

gender, men in the control group scored significantly higher than women in the MS group $(\mathrm{p}<0.01)$. There was no significant difference between men and women in the patient group ( women's average score $=39.3$; men's average score $=37$ ).

High levels of empathy were observed in $15 \%$ of the control subjects, while none of the patients with MS could be classified in this category $(\mathrm{p}<0.0001)$.

There was no correlation between the levels of empathy and disease duration (Pearson's $=0.12$ ) or neurological disability (Pearson's $=0.079$ ) among the patients. Likewise, no predominance of low levels of empathy could be attributed to lesions in particular areas of the brain on magnetic resonance imaging. There were no patterns of use of disease-modifying drugs associated with findings of empathy in patients.

\section{DISCUSSION}

Despite inherent limitations of a cross-sectional study assessing a relatively small sample of patients with different psychosocial and economic backgrounds, and with variable degrees of family support, the present study could draw significant results. The conclusion from this work was that patients with MS showed lower degrees of empathy, irrespective of disease duration or neurological disability. No specific areas of the brain were affected by demyelination or atrophy among patients with lower levels of empathy. These findings have added more data to the literature, and are in agreement with previous reports ${ }^{10,11}$. However, it must be highlighted that this study is not free of potential bias: patients and controls may have had difficulty in expressing their feelings in the short sentences used by this instrument. Among the strong points of this paper, it is perhaps the individual interview, always by the same examiner, that brings more credit to the study design. The instrument has been validated and used in several situations, but it is new for $\mathrm{MS}^{19}$.

Patients with MS have to live with a chronic and potentially disabling neurological disease that renders them vulnerable to a variety of social and professional situations ${ }^{20,21}$. It is necessary that relatives, friends and employers of patients with MS become aware of this low degree of empathy that may render the patient compassionless and uninterested in the suffering of other human beings. It is essential that those caring for these patients propose methods to approach this behavior and to improve the patients' relations with family, friends and fellow workers ${ }^{22}$.

\section{References}

1. Cerqueira AC, Semionato de Andrade P, Godoy Barreiros JM, Teixeira AL, Nardi AE. Psychiatric disorders in patients with multiple sclerosis. Compr Psychiatry. 2015;63:10-4. doi:10.1016/j.comppsych.2015.08.001

2. Tallantyre EC, Bø L, Al-Rawashdeh O, Owens T, Polman CH, Lowe JS et al. Clinico-pathological evidence that axonal loss underlies disability in progressive multiple sclerosis. Mult Scler. 2010;16(4):406-11. doi:10.1177/1352458510364992

3. Carlozzi AF, Bull KS, Stein LB, Ray K, Barnes L. Empathy theory and practice: a survey of psychologists and counselors. J Psychol. 2002;136(2):161-70. doi:10.1080/00223980209604147

4. Ben-Ami Bartal I, Decety J, Mason P. Empathy and pro-social behavior in rats. Science. 2011;334(6061):1427-30. doi:10.1126/science.1210789

5. Freidin E, Carballo F, Bentosela M. Direct reciprocity in animals: the roles of bonding and affective processes. Int J Psychol. 2015. doi:10.1002/ijop.12215

6. Van Horn JD, Irimia A, Torgerson CM, Chambers MC, Kikinis R, Toga AW. Mapping connectivity damage in the case of Phineas Gage. PLoS One. 2012;7(5):e37454. doi:10.1371/journal.pone.0037454

7. Thiebaut de Schotten M, Dell'Acqua F, Ratiu P, Leslie A, Howells $\mathrm{H}$, Cabanis E et al. From Phineas Gage and Monsieur Leborgne to H.M.: revisiting disconnection syndromes. Cereb Cortex. 2015;25(12):4812-27. doi:10.1093/cercor/bhv173
8. Nienhuis JB, Owen J, Valentine JC, Winkeljohn Black S, Halford TC, Parazak SE et al. Therapeutic alliance, empathy, and genuineness in individual adult psychotherapy: a meta-analytic review. Psychother Res. 2016;7:1-13. doi:10.1080/10503307.2016.1204023

9. Valk P, Amor S. Preactive lesions in multiple sclerosis. Curr Opin Neurol. 2009;22(3):207-13. doi:10.1097/WC0.0b013e32832b4c7

10. Kraemer M, Herold M, Uekermann J, Kis B, Wiltfang J, Daum I et al. Theory of mind and empathy in patients at an early stage of relapsing remitting multiple sclerosis. Clin Neurol Neurosurg. 2013;115(7):1016-22. doi:10.1016/j.clineuro.2012.10.027

11. Gleichgerrcht E, Tomashitis B, Sinay V. The relationship between alexithymia, empathy and moral judgment in patients with multiple sclerosis. Eur J Neurol. 2015;22(9):1295-303. doi:10.1111/ene.12745

12. Polman $\mathrm{CH}$, Reingold SC, Banwell B, Clanet M, Cohen JA, Filippi $M$ et al. Diagnostic criteria for multiple sclerosis: 2010 Revisions to the McDonald criteria. Ann Neurol..2011;69(2):292-302. doi:10.1002/ana.22366

13. Zigmond AS, Snaith RP. The hospital anxiety and depression scale. Acta Psychiatr Scand. 1983;67(6):361-70. doi:10.1111/j.1600-0447.1983.tb09716.x

14. Baron-Cohen S, Wheelwright S. The empathy quotient: an investigation of adults with Asperger syndrome or high functioning autism, and normal sex differences. J Autism Dev Disord. 2004;34(2):163-75. doi:10.1023/B:JADD.0000022607.19833.00 
15. Rodrigues J, Lopes A, Giger JC et al. Escalas de medição do Quociente de Empatia/Sistematização: um ensaio de validação para a população portuguesa. Psicologia.. 2011;25:73-89.

16. Schiffer B, Pawliczek C, Müller BW, Gizewski ER, Walter H. Why don't men understand women? Altered neural networks for reading the language of male and female eyes. PLoS One. 2013;8(4):e60278. doi:10.1371/journal.pone.0060278

17. Baron-Cohen S, Cassidy S, Auyeung B, Allison C, Achoukhi M, Robertson $\mathrm{S}$ et al. Attenuation of typical sex differences in 800 adults with autism vs. 3,900 controls. PLoS One. 2014;9(7):e102251. doi:10.1371/journal.pone.0102251

18. Kurtzke JF. Rating neurologic impairment in multiple sclerosis: an expanded disability status scale (EDSS). Neurology. 1983:33(11):1444-52. doi:10.1212/WNL.33.11.1444
19. Lawrence EJ, Shaw P, Baker D, Baron-Cohen S, David AS. Measuring empathy: reliability and validity of the Empathy Quotient. Psychol Med. 2004;34(5):911-9. doi:10.1017/S0033291703001624

20. Giovannetti AM, Brambilla L, Torri Clerici V, Antozzi C, Mantegazza R, Černiauskaite M et al. Difficulties in adjustment to multiple sclerosis: vulnerability and unpredictability of illness in the foreground. Disabil Rehabil. 2016:1-7. doi:10.3109/09638288.2016.1170212

21. Uccelli MM. The impact of multiple sclerosis on family members: a review of the literature. Neurodegener Dis Manag. 2014;4(2):177-85. doi:10.2217/nmt.14.6

22. Lysandropoulos AP, Havrdova E; ParadigMS Group. 'Hidden' factors influencing quality of life in patients with multiple sclerosis. Eur J Neurol. 2015;22[Suppl 2]:28-33. doi:10.1111/ene.12801 